Abstracta Iranica Abstracta Iranica

Revue bibliographique pour le domaine irano-aryen

Volume 22 | 2001

Comptes rendus des publications de 1999

Provisional report of researches on historical sites and inscriptions in Mongolia from 1996 to 1998. The Society of Central Eurasian Studies, Osaka University, 1999. [mostly in Japanese]

Nicholas Sims-Williams

(2) OpenEdition

Journals

Édition électronique

URL : http://journals.openedition.org/abstractairanica/36186

DOI : 10.4000/abstractairanica.36186

ISSN : 1961-960X

Éditeur :

CNRS (UMR 7528 Mondes iraniens et indiens), Éditions de l'IFRI

Édition imprimée

Date de publication : 15 mai 2001

ISSN : 0240-8910

Référence électronique

Nicholas Sims-Williams, « Provisional report of researches on historical sites and inscriptions in Mongolia from 1996 to 1998. The Society of Central Eurasian Studies, Osaka University, 1999. [mostly in Japanese] », Abstracta Iranica [En ligne], Volume 22 | 2001, document 54, mis en ligne le 15 février 2010, consulté le 09 octobre 2020. URL : http://journals.openedition.org/abstractairanica/36186 DOI : https://doi.org/10.4000/abstractairanica.36186

Ce document a été généré automatiquement le 9 octobre 2020.

Tous droits réservés 


\section{Provisional report of researches on historical sites and inscriptions in Mongolia from 1996 to 1998. The Society of Central Eurasian Studies, Osaka University, 1999. [mostly in Japanese]}

Nicholas Sims-Williams

The monuments surveyed include the inscriptions of Bugut, Qara-balgasun and Sevrey, the Sogdian versions of which are here edited and translated (into English) by Yutaka Yoshida.

\section{INDEX}

Thèmes : 2.1. Langues anciennes

\section{AUTEURS}

NICHOLAS SIMS-WILLIAMS

Université de Londres (Grande-Bretagne) 